Arch. hist. jap. Vol. 16, n. 1 (January 1959).

P. $69-79$.

Anat. Labor., Fac. of Agriculture, Tohoku Univ. (Director: Prof. Y. TORYU).

\title{
Differential Counts of Glycogen-free and Glycogen-laden Ova in Rat Ovaries during Estrous Cycle, Pregnancy and Lactation.
}

\author{
性周期，妊娠期及び泌乳期に於けるラット卵巣中のグリコーゲン \\ 含有卵及びグリコーゲン不含有卵の数の比較。
}

\section{Kazuo ISHIDA 石田一夫.}

(Received November 10, 1958.)

Histochemical studies of glycogen in the rat ovaries have been made by many investigators : TOGARI (1927), BRANDENBURG (1938), and HARTER (1948). They reported that the ova in the normal and atretic follicles had a large amount of glycogen, but other cells had not.

In a previous paper (1952), however, the author reported that some ova in adult rats had no glycogen, while others had a small to a large amount of glycogen. He (1958) further stated that the number of glycogen-free ova was affected by various dietary conditions, whereas that of glycogen-laden ova was little affected.

In the present investigation, the author has dealt with the number of glycogenfree and glycogen-laden ova in the rat ovaries during the estrous cycle, pregnancy and lactation.

\section{Materials and Methods.}

Twenty-four rats ranging from 12 to 15 months of age were used. Five of them were used at the estrous cycle stage, five on the 18th day of pregnancy, seven on the 30 th day of lactation, and seven on the 30th day after weaning when estrous cycles are present. These rats were obtained from our laboratory colony which had been

Table 1. Average weight of organs.

\begin{tabular}{|c|c|c|c|c|c|c|c|c|c|}
\hline Stages & $\begin{array}{c}\text { Number } \\
\text { of } \\
\text { rats } \\
\text { used }\end{array}$ & $\begin{array}{l}\text { Body } \\
\text { weight } \\
(\mathrm{g})\end{array}$ & $\begin{array}{c}\text { Ovary } \\
\text { weight } \\
(\mathrm{mg})\end{array}$ & $\begin{array}{c}\text { Oviduct } \\
\text { weight } \\
(\mathrm{mg})\end{array}$ & $\begin{array}{l}\text { Uterus } \\
\text { weight } \\
(\mathrm{mg})\end{array}$ & $\begin{array}{l}\text { Number } \\
\text { of fetus } \\
\text { or } \\
\text { sackling }\end{array}$ & $\begin{array}{c}\text { Vagina } \\
\text { weight } \\
(\mathrm{mg})\end{array}$ & $\begin{array}{l}\text { Pitui- } \\
\text { tary } \\
\text { weight } \\
\text { ( } \mathrm{mg})\end{array}$ & $\begin{array}{c}\text { Adrenal } \\
\text { weight } \\
\text { (mg) }\end{array}$ \\
\hline $\begin{array}{l}\text { Estrous } \\
\text { cycle }\end{array}$ & 5 & 227 & 32 & 10 & 655 & & 196 & 13 & 29 \\
\hline Pregnanc* & 5 & 235 & 43 & 10 & $14153^{\bigcirc}$ & 11 & 257 & 11 & 30 \\
\hline Lactation $* *$ & 7 & 172 & 29 & 8 & 262 & 8 & 183 & 10 & 28 \\
\hline $\begin{array}{l}\text { Estrous } * * * * \\
\text { cycle after } \\
\text { weaning }\end{array}$ & 7 & 221 & 33 & 10 & 543 & & 180 & 12 & 27 \\
\hline
\end{tabular}


maintained as a closely inbred strain for many years. The rats were weighed and killed by decapitation at the desired time. Then the ovaries, oviducts, uteri, vaginae, pituitaries and adrenals were weighed with the results given in Table 1.

The ovaries were fixed in neutral alcohol-formalin solution, embedded in paraffin, cut serially at $8 \mu$ and stained by the periodic acid-SCHIFF method.

In this investigation, the ova in the primary, secondary and GRAAFian follicles were counted.

\section{Results.}

\section{A. Results obtained about the normal ova.}

Number of normal ova: The normal ova in the primary, secondary and GRAAFian follicles were counted at the stages of estrous cycle, pregnancy, lactation and estrous cycle after weaning. The results are given in Table 2.

Table 2. Number of normal ova in the primary, secondary and GRAAFian follicles.

\begin{tabular}{c|c|c|c|c}
\hline \multicolumn{1}{c|}{ Ova } & \multicolumn{3}{|c}{ Stages } \\
\hline & $\begin{array}{c}\text { Estrous } \\
\text { cycle }\end{array}$ & Pregnancy & Lactation & $\begin{array}{c}\text { Estrous cycle } \\
\text { after weaning }\end{array}$ \\
\hline $\begin{array}{l}\text { Ova in the primary } \\
\text { follicles } \\
\text { Ova in the secondary } \\
\text { and GRAAFian follicles }\end{array}$ & $112 \pm 11.4$ & $96 \pm 9.9$ & $55 \pm 6.6^{*}$ & $110 \pm 12.2$ \\
\hline \multicolumn{1}{c|}{ Total } & $157 \pm 14.9$ & $116 \pm 12.0^{*}$ & $86 \pm 9.3^{*}$ & $177 \pm 18.4$
\end{tabular}

Confidence interval: $\boldsymbol{\alpha}=0.1$, significant difference from estrous cycle stage : by * P less than 0.005 .

As shown in Table 2, the number of the normal ova in the primary follicles was less at the pregnancy stage than at the estrous cycle stage, showing a significant difference. No significant differences were found in the number of normal ova between the stages of estrous cycle and lactation, or between the former and the stage of estrous cycle after weaning. As shown in the same table, the normal ova in the secondary and GRAAFian follicles were statistically less at the lactation stage than at the estrous cycle stage, while no differences in the number were found between the stages of estrous cycle and pregnancy, or between the former and the stage of estrous cycle after weaning. From the results mentioned above, it was noticed that the total number of the normal ova in these follicles was less at the stages of pregnancy and lactation than at the stage of estrous cycle, but no difference in the number was found between the stages of estrous cycle and estrous cycle after weaning.

Glycogen-free and glycogen-laden ova: As already reported in a previous paper (1952), none of the ova in the primary follicles possessed any glycogen (Fig. 1), while most ova in the secondary and GRAAFian follicles contained a small to a large amount of glycogen and some ova contained none (Figs. 2 and 3). 
In the present investigation, glycogen-laden ova were counted at the stages of estrous cycle, pregnancy, lactation and estrous cycle after weaning, and the results are given in Table 3.

Table 3. Number of glycogen-free and glycogen-laden ova in the secondary and GRAAFian follicles.

\begin{tabular}{|c|c|c|c|c|}
\hline \multirow[b]{2}{*}{ Ova } & \multicolumn{4}{|c|}{ Stages } \\
\hline & $\begin{array}{l}\text { Estrous } \\
\text { cycle }\end{array}$ & Pregnancy & Lactation & $\begin{array}{l}\text { Estrous cycle } \\
\text { after weaning }\end{array}$ \\
\hline Glycogen-free ova & $15 \pm 5.7$ & $70 \pm 9.6^{* *}$ & $26=4.4^{*}$ & $22 \pm 6.2$ \\
\hline $\begin{array}{l}\text { Ova containing a small } \\
\text { amount of glycogen }\end{array}$ & $32 \pm 4.1$ & $17 \pm 3.6^{* *}$ & $17 \pm 3.8^{* *}$ & $37 \pm 7.1$ \\
\hline $\begin{array}{l}\text { Ova containing a large } \\
\text { amount of glycogen }\end{array}$ & $65 \pm 10.2$ & $8 \pm 2.0^{* *}$ & $12 \pm 1.4^{* *}$ & $51 \pm 5.9$ \\
\hline Total glycogen-laden ova & $97 \pm 11.0$ & $26 \pm 4.3^{* *}$ & $29 \pm 3.4^{* *}$ & $88 \pm 9.6$ \\
\hline The sum total & $112 \pm 11.4$ & $96 \pm 9.9$ & $55 \pm 6.6^{* * *}$ & $110 \div 12.2$ \\
\hline
\end{tabular}

Confidence interval: $\boldsymbol{\alpha}=0.1$, significant difference from estrous cycle stage: by ** P less than 0.005 , by $* \mathrm{P}$ less than 0.025 .

As shown in Table 3, the glycogen-free ova were more at the stages of pregnancy and lactation than at the estrous cycle stage, but were almost the same at the stages of estrous cycle and that after weaning. On the contrary, the glycogenladen ova were much less at the stages of pregnancy and lactation than at the estrous cycle stage, while there was no significant difference in the number between the stages of estrous cycle and of that after weaning.

Ova in the large GRAAFian follicles: The glycogen-free and glycogen-laden ova in the large GRAAFian follicles of $400 / \ell$ or more in diameter were counted, and the results are given in Table 4.

Table 4. Number of glycogen-free and glycogen-laden ova in the large GRAAFian follicles of $400 / \ell$ or more in diameter.

\begin{tabular}{|c|c|c|c|c|}
\hline & \multicolumn{4}{|c|}{ Stages } \\
\hline Ova & $\begin{array}{c}\text { Estrous } \\
\text { cycle }\end{array}$ & Pregnancy & Lactation & $\begin{array}{l}\text { Estrous cycle } \\
\text { after weaning }\end{array}$ \\
\hline Glycogen-free ova & $1 \pm 0.8$ & $16 \pm 2.8^{* *}$ & $6 \pm 1.4^{*}$ & $1 \pm 0.8$ \\
\hline Glycogen-laden ova & $11 \pm 1.2$ & $2 \pm 1.3^{* *}$ & $5 \pm 1.1^{* *}$ & $11 \pm 0.2$ \\
\hline Total & $12 \pm 1.0$ & $18 \pm 2.0^{* *}$ & $11 \div 1.4$ & $12 \pm 1.5$ \\
\hline
\end{tabular}

Confidence interval: $\boldsymbol{\alpha}=0.1$, significant difference from estrous cycle stage: ** $\mathrm{P}$ less than $0.005, * \mathrm{P}$ less than 0.025 .

As shown in Table 4, the glycogen-free ova were more at the stages of pregnancy and lactation than at the stage of estrous cycle, but no difference in the 
number was found between the stages of estrous cycle and estrous cycle after weaning. As for glycogen-laden ova, however, the number was much smaller at the stages of pregnancy and lactation, while no difference in the number was found between the stage of estrous cycle and that of estrous cycle after weaning.

\section{B. Results obtained about the atretic ova.}

As already reported in a previous paper (1953), the atrophying pictures of the ova in the primary follicles differ greatly from those in the secondary and GRAAFian ones: When the primary follicles are doomed to destruct the ova shrink and degenerate (Fig. 4). While, the atrophy of the ova in the secondary and GRAAFian follicles is very complicated. The first sign of degenerating ova is the appearance of pseudomaturation spindle. Afterwards, the ova begin to atrophy through one of the three kinds of degenerating process as follows :

(a) The nucleus of the ovum shows the piknosis, and its cytoplasm shrinks (Fig. 5).

(b) The ovum performs an equal cell division, and then the cytolasm becomes irregular cell masses and finally disappears (Fig. 6).

(c) The cytoplasm of the ovum performs an irregular cell division to form irregular cell masses, and finally they disappear.

Number of atretic ova: The atretic ova were counted at the stages of estrous cycle, pregnancy, lactation and estrous cycle after weaning. The results are given in Table 5. In Table 5 are also given the results obtained from the glycogen-free and glycogen-laden atretic ova in these stages.

As shown in Table 5, no significant differences in the number of atretic ova in the primary follicles were found between the stages of estrous cycle and pregnancy, or lactation, or estrous cycle after weaning. The atretic ova in the secondary and GRAAFian follicles were less at the lactation stage than at the estrous cycle stage. No significant differences were found between the stages of estrous cycle and pregnancy, or estrous cycle after weaning. A similar relation was found in the total of the ova in the primary, secondary and GRAAFian follicles.

Glycogen-free and glycogen-laden ova: Glycogen-free and glycogen-laden atretic ova in the secondary and GRAAFian follicles were counted. The atretic ova in the primary ones contained no glycogen (Fig. 4).

As shown in Table 5, the glycogen-f ree ova were more at the pregnancy stage than at the estrous cycle one. No significant differences in the number were found between the stages of estrous cycle and lactation, or estrous cycle after weaning. The glycogen-laden ova were less at the lactation stage than at the estrous cycle one, while no significant differences in the number were found between the stages of estrous cycle and pregnancy, or estrous cycle after weaning.

Cleaved atretic ova: As shown in Table 5, the cleaved atretic ova were less at the lactation stage than at the estrous cycle one, showing a significant difference. No significant differences in the number were found between the stages of estrous cycle and pregnancy, or estrous cycle after weaning. These cleaved ova always contained a large amount of glycogen. 
Table 5. Number of atretic ova and the comparison of glycogen-free and glycogen-laden atretic ova.

\begin{tabular}{|c|c|c|c|c|}
\hline \multirow[b]{2}{*}{ Atretic ova } & \multicolumn{4}{|c|}{ Stages } \\
\hline & $\begin{array}{l}\text { Estrous } \\
\text { cycle }\end{array}$ & Pregnancy & Lactation & $\begin{array}{l}\text { Estrous cycle } \\
\text { after weaning }\end{array}$ \\
\hline $\begin{array}{l}\text { Ova in the primary follic- } \\
\text { les }\end{array}$ & $11 \pm 10.0$ & $1 \pm 1.0$ & $4 \pm 1.3$ & $13 \pm 5.0$ \\
\hline $\begin{array}{l}\text { Ove in the secondary and } \\
\text { GRAAFian follicles }\end{array}$ & $17 \pm 2.5$ & $21+5.9$ & $7 \pm 2.2^{* *}$ & $15 \pm 5.2$ \\
\hline Total & $28 \pm 10.7$ & $22 \pm 6.1$ & $11 \pm 2.5^{* *}$ & $28 \pm 8.5$ \\
\hline $\begin{array}{l}\text { Glycogen-free ova in the } \\
\text { secondary and GRAAFi- } \\
\text { an follicles }\end{array}$ & $2 \pm 1.0$ & $13 \pm 3.7 * *$ & $4 \pm 1.3$ & $2 \pm 1.1$ \\
\hline $\begin{array}{l}\text { Glycogen-laden ova in the } \\
\text { secondary and GRAAFi- } \\
\text { an follicles }\end{array}$ & $15 \pm 3.5$ & $8 \pm 2.5$ & $3 \pm 1.5^{* *}$ & $13 \pm 4.1$ \\
\hline $\begin{array}{l}\text { Glycogen-free cleaved } \\
\text { ova }\end{array}$ & 0 & 0 & 0 & 0 \\
\hline $\begin{array}{l}\text { Glycogen-laden cleaved } \\
\text { ova }\end{array}$ & $3 \pm 1.9$ & $2+0.8$ & $0.4+0.28^{*}$ & $1 \pm 0.8$ \\
\hline Total & $3 \pm 1.9$ & $2 \pm 0.8$ & $0.4 \pm 0.28^{*}$ & $1 \pm 0.8$ \\
\hline
\end{tabular}

Confidence interval: $\boldsymbol{\alpha}=0.1$, significant difference from estrous cycle stage : ** $\mathrm{P}$ less than 0.005 , * $\mathrm{P}$ less than 0.025 .

\section{Results obtained about the corpora lutea.}

The corpora lutea in the ovaries were counted, and the results are given in Table 6.

As shown in Table 6, the corpora lutea were less at the stages of pregnancy and lactation than at the estrous cycle stage. No difference in the number was found between the stages of estrous cycle and of that after weaning.

Table 6. Number of corpora lutea.

\begin{tabular}{c|c|c|c|c}
\hline & \multicolumn{3}{|c}{ Stages } \\
\hline Corpora lutea & $\begin{array}{c}\text { Estrous } \\
\text { cycle }\end{array}$ & Pregnancy & Lactation & $\begin{array}{c}\text { Estrous cycle } \\
\text { after weaning }\end{array}$ \\
\hline Small corpora lutea & $5 \pm 2.6$ & $2 \pm 0.7$ & $1 \pm 0.7$ & $6 \pm 1.9$ \\
Large corpora lutea & $27 \pm 4.1$ & $11 \pm 1.9^{*}$ & $15 \pm 4.0^{*}$ & $39 \pm 5.0$ \\
\hline Total & $32 \pm 4.7$ & $13 \pm 1.7^{*}$ & $16 \pm 4.3^{*}$ & $45 \pm 6.1$
\end{tabular}

Confidence interval : $\alpha=0.1$, significant difference from estrous cycle stage :

* P less than 0.005 . 


\section{Discussion.}

It is demonstrated from the results described in Section A that the glycogen-free normal ova in the secondary and GRAAFian follicles increase at the stages of pregnancy and lactation as compared with those at the estrous cycle stage, whereas the glycogen-laden ones decrease. At the stage of estrous cycle after weaning, both the glycogen-free and glycogen-laden ova reach the same level as those at the estrous cycle stage.

It is noticed that the decrease of glycogen-laden ova at the lactation stage may due to the result of the decrease in total number of normal ova, while that of glycogen-laden ova at the pregnancy stage is clearly true because the total number at that stage shows no difference from that at the estrous cycle stage. Therefore, the ratio of the glycogen-free and glycogen-laden ova to the total number of normal ova was calculated, and the results are given in Table 7 .

Table 7. Ratio of glycogen-free and glycogen-laden ova to the total (\%).

\begin{tabular}{c|c|c|c|c}
\hline & \multicolumn{3}{|c}{ Stages } \\
\hline Ova & $\begin{array}{c}\text { Estrous } \\
\text { cycle }\end{array}$ & Pregnancy & Lactation & $\begin{array}{c}\text { Estrous cycle } \\
\text { after weaning }\end{array}$ \\
\hline
\end{tabular}

In the secondary and GRAAFian follicles.

\begin{tabular}{l|c|c|c|c}
\hline $\begin{array}{l}\text { Glycogen-free ova } \\
\begin{array}{l}\text { Ova containing a small } \\
\text { amout of glycogen }\end{array}\end{array}$ & 12.9 & 74.2 & 46.4 & 21.9 \\
$\begin{array}{l}\text { Ova containing a large } \\
\text { amount of glycogen }\end{array}$ & 57.0 & 15.7 & 30.4 & 29.1 \\
\hline \begin{tabular}{l} 
Total glycogen-laden ova \\
\hline
\end{tabular}
\end{tabular}

In the large GRAAFian follicles.

\begin{tabular}{l|r|r|r|l}
\hline Glycogen-free ova & 7.9 & 85.5 & 50.9 & 10.4 \\
Glycogen-laden ova & 92.1 & 14.5 & 49.1 & 89.6 \\
\hline
\end{tabular}

In the atretic follicles (secondary and GRAAFian).

\begin{tabular}{l|l|l|l|l}
\hline Glycogen-free ova & 11.8 & 61.9 & 57.1 & 13.3 \\
Glycogen laden ova & 88.2 & 38.1 & 42.9 & 86.7
\end{tabular}

As shown in Table 7, in the secondary and GRAAFian follicles, the percentage of the glycogen-free ova was higher at the stages of pregnancy and lactation than at the stages of estrous cycle and that after weaning, whereas that of the glycogenladen ova was lower at the former two stages. A similar tendency was found in the large GRAAFian follicles.

As shown in Table 7, the percentage of the glycogen-free atretic ova was higher at the stages of pregnancy and lactation than at the other stages, whereas that of the glycogen-laden ova was lower at these stages, nearly coinciding with the results about the normal ova in the secondary and GRAAFian follicles. 
In a previous paper (1953), the author reported of the appearance of atretic ova at the estrous cycle stage, showing an equal cell division, always with a large amount of glycogen within. In the present investigation, such atretic ova appeared at the stages of pregnancy and lactation as well as at the stage of estrous cycle.

From the fact that all ovulated normal ova contained a large amound of glycogen (1952) and all cleaved atretic ova also possessed a large amount of it, it is suspected that the glycogen may play an important role for the cell division.

In a previous paper (1958), the author also reported that the number of glycogen-free ova was affected by various dietary conditions, whereas that of glycogenladen ova was little affected by those. In the present investigation, an alteration in the number of the glycogen-laden ova was observed: that is, these ova decreased at the stages of pregnancy and lactation as compared with the stage of estrous cycle.

\section{Summary.}

The results obtained in this investigation are summarized as follows:

1. The glycogen-free ova in the secondary and GRAAFian follicles at the stages of pregnancy and lactation increased as compared with those at the estrous cycle stage, whereas glycogen-laden ones decreased at those stages, and at the stage of estrous cycle after weaning both the glycogen-free and glycogen-laden ova reached the same level as those at the estrous cycle stage. The percentage of the glycogenfree ovaw as higher at the stages of pregnancy and lactation than at the stages of estrous cycle and that after weaning, whereas that of the glycogen-laden ova was lower at the former two stages.

2. The glycogen-free atretic ova in the secondary and GRAAFian follicles increased at the pregnancy stage as compared with those at the estrous cycle one. The glycogen-laden ova decreased at the lactation stage. At the stage of estrous cycle after weaning, both the glycogen-free and glycogen-laden ova reached the same level as those at the estrous cycle stage. The percentage of the glycogen-free atretic ova was higher at the stages of pregnancy and lactation than at the stages of estrous cycle and of estrous cycle after weaning, whereas that of the glycogenladen ova was lower at the stages of pregnancy and lactation, nearly coinciding with the results about the normal ova in the secondary and GRAAFian follicles.

3. The corpora lutea at the stages of pregnancy and lactation decreased as compared with those at the stage of estrous cycle, and then at the stage of estrous cycle after weaning, the corpora lutea reached the same level as those at the stage of estrous cycle.

Acknowledgment: The author wishes to express his hearty thanks to Prof. Y. TORYU for his valuable guidance through the course of this work.

\section{内 容 自 抄}

ラットの第 1 次卵胞中の卵は夫れむグリコーゲンを含んでいないが，第 2 次及 び Graaf 氏卵胞ゆの卵にはグリコーゲンを含んでいるものと含んでいない屯のと がある、本論文は之等グリコーゲンを含有する卵と含有しない卵の数を性周期, 
妅娠期及び泌乳期に就て比較検討したあのである。

採取した卵巣は中性アルコールーホルマリン液に固定，パラフィンに包埋して 8 の連続切片とした。グリコーゲンの染色には過沃度酸-Schiff 法を用いた。結 果の主なるあのは次の通りである.

第 2 次及び Graaf 氏卵胞中のグリコーゲンを含まない卵は好娠期及び泌乳期 に增加する，之に反してグリコーゲン含有卵は之等の時期に著しく減少する。し かしながら離乳後には卵は妅艮前の数に戻る。萎縮卵に就ても正常卵の場合と類 似の傾向がみられる。

黄保は妅:娠期及び泌乳期に減少するが離乳後には姬娠前の数に戻る.

\section{References.}

Brandenburg, W.: Das Glykogen in Eierstock der Ratte. Z. mik-anat. Forsch. 43 (1938). - Harter, B. T. : Glycogen and carbohydrate-protein complex in the ovary of the white rat during the oestrous cycle. Anat. Rec. 102 (1948). —Ishida, K. : Histochemical studies of rat ova with special reference to glycogen of them after ovulation. Tohoku J. Agr. Res. 3 (1952). - Ishida, K.: Morphological and histochemical studies of atretic ova. Tohoku J. Agr. Res. 4 (1953). - Ishida, K. : Comparison in the number of glycogenfree and glycogen-laden ova in rat ovaries under various dietary conditions. Tohoku J. Agr. Res. 9 (1958). - Togari, Ch.: On the appearance of glycogen in the female reproductive glands of rodents with special reference to their histology. Fol. anat. jap. 5 (1927). 
Plate-figures. 


\section{Exp1anation of Plate-figures.}

All sections were stained by the periodic acid-SCHIFF method. $\times 200$.

Fig. 1. The ovum in the primary follicle contains no glycogen.

Fig. 2. The ovum in the GRAAFian follicle contains no glycogen.

Fig. 3. The ovum in the GRAAFian follicle contains a large amount of glycogen.

Fig. 4. The atretic ovum with a degenerated cytoplasm in the primary follicle contains no glycogen.

Fig. 5. The atretic ovum with a piknotic nucleus and degenerated cytoplasm in the GRAAFian follicle contains a large amount of glycogen.

Fig. 6. The cleaved atretic orum in the GRAAFian follicle contains a large amount of glycogen. 
K. IS IIIJA.
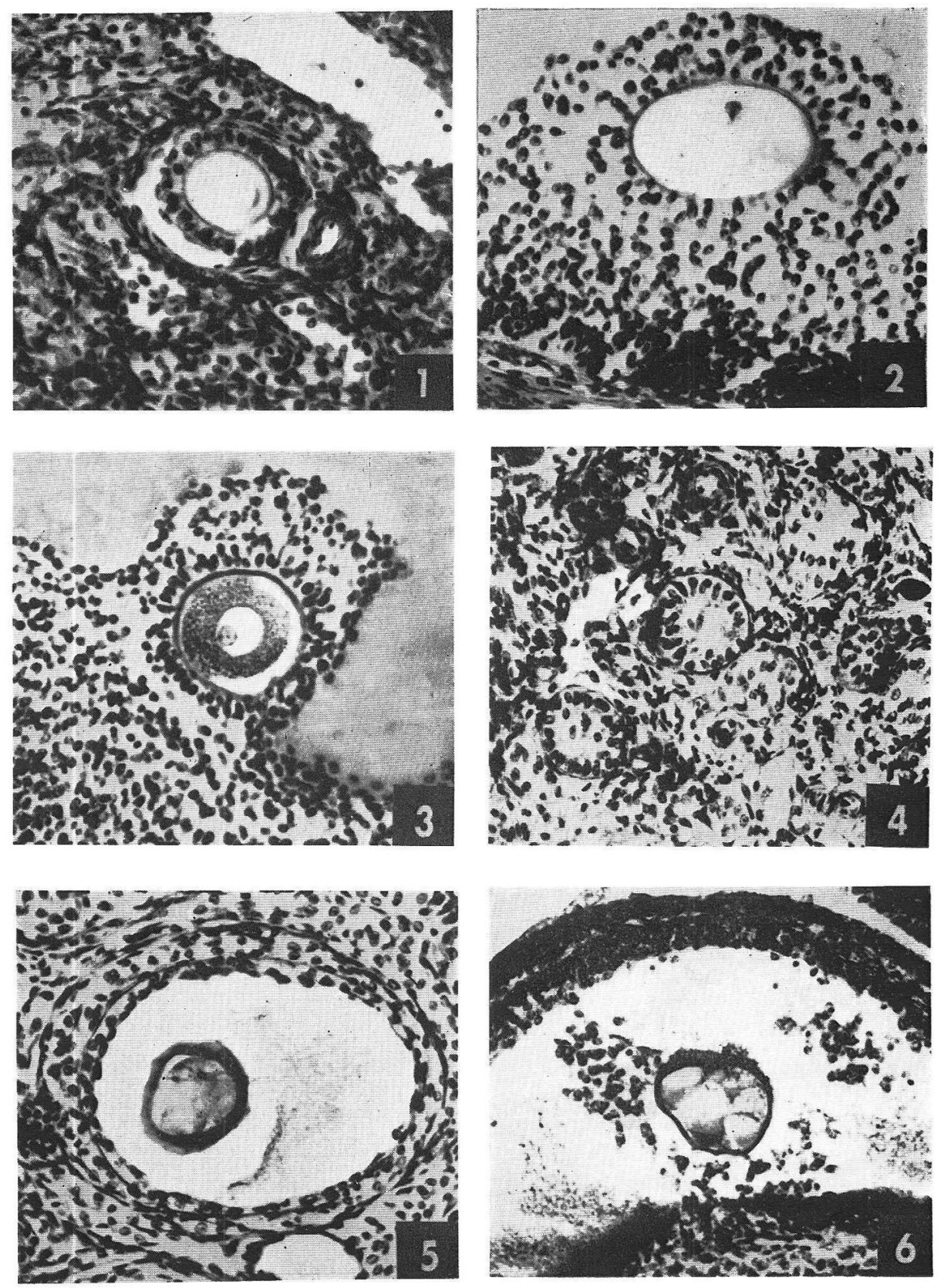